EDUKACJA MIĘDZYKULTUROWA

2018, nr 1 (8)

ISSN 2299-4106

DOI: $10.15804 / \mathrm{em} .2018 .01 .03$

Jolanta Miluska

\title{
Małżeństwo w perspektywie badań międzykulturowych
}

Streszczenie: Rozwój psychologii kulturowej i badań międzykulturowych dostarcza nowych narzędzi opisu i analizy instytucji małżeństwa. Jest ono już nie tylko systemem o określonych funkcjach, ale także związkiem, którego cechy i sposób funkcjonowania są w istotnym stopniu regulowane przez wartości i normy kulturowe. Koncepcje wartości kulturowych stanowią dobrą podstawę interpretacji życia małżeńskiego w kontekście porównań różnych systemów wartości. Wyjaśniają one, jak definiowana jest miłość jako ważna zasada doboru w pary i jak kształtują się relacje małżeńskie (władza, atrakcyjność wzajemna, komunikowanie się, konflikty i negocjacje), szczególnie w przypadku małżeństw wielokulturowych, do których partnerzy wnoszą różne doświadczenia i tradycje.

Słowa kluczowe: psychologia kulturowa, małżeństwo, małżeństwo wielokulturowe, badania międzykulturowe

\section{Kulturowa specyfika małżenstwa}

Małżeństwo jest to „związek kobiety i mężczyzny, będący podstawą rodziny, występujący u wszystkich znanych ludów i zmieniający się wraz z ich historią. Charakter i struktura małżeństwa zależą od typu kultury" (Nowa Encyklopedia Powszechna PWN, 1997, s. 65), choć jednocześnie jego funkcjonowanie warunkują także czynniki ekonomiczne i demograficzne determinujące np. wiek osób zawierających małżeństwo.

Ludzie od tysięcy lat decydują się na zawarcie związku małżeńskiego. Łączenie się w pary jest w pewien sposób zakodowane w naszej ludzkiej naturze (Samson, 2001). Wcześniejsze rozumienie małżeństwa różniło się od tego, które obowiązuje współcześnie. Kiedyś zawarcie małżeństwa określane było zgodnie z obyczajami i wierzeniami, które obowiązywały w danej społeczności. W Europie, jako pierwsza stworzona została kościelna doktryna małżeństwa, która głosiła, że małżeństwo jako boska instytucja jest nierozerwalne. W oparciu o tradycję związku małżeńskiego sformułowaną przez kościół po- 
wstał jej prawny odpowiednik. W dzisiejszych czasach zawarcie małżeństwa podlega określonym normom prawnym, obyczajowym i religijnym (Janicka i Niebrzydowski, 1994). Normy te odnoszą się do praw i obowiązków partnerów oraz pełnionych przez nich ról społecznych.

Rola wartości regulujących zachowanie małżonków ujawnia się już w klasyfikacji typów małżeństw. Najbardziej znane, tradycyjny i egalitarny modele małżeństwa wyrażają odmienne koncepcje podziału i charakteru relacji pomiędzy małżonkami (Kaźmierczak, 2008), u podstaw których znajdują się przekonania na temat odmiennych ich atrybutów związanych z płcią oraz rodzaju wartości, które w najwyższym stopniu je wyrażają i wzmacniają. Przekonania te niekoniecznie są dokumentowane wynikami licznych badań, w których - przy uwzględnieniu wieku i kontekstu kulturowego oraz stosowanych metod badawczych stwierdza się istnienie tylko małych, choć podobnych różnic w zakresie osobowości kobiet i mężczyzn (McCrae i in., 2005, Schmitt i in., 2008). Spostrzegane różnice płciowe interpretowane w kategoriach stereotypów płciowych, badane między innymi w dużej próbie osób pochodzących z 26 krajów poszerzonym narzędziem NCS zawierających 30 bipolarnych itemów (Terracciano i in., 2005) korespondujących z NEO-PI-R (Costa, McCrae, 1992) mogą jednak wyjaśniać, dlaczego w sferze społecznej kobietom i mężczyznom przyznawane są odmienne role. Kobiety były spostrzegane wyżej niż mężczyźni na czterech głównych wymiarach (neurotyzm, otwartość na doświadczenie, ugodowość i sumienność), poza wymiarem ekstrawersji. Szczegółowa analiza dotycząca tych wymiarów wskazała, iż uzyskały one wyższy niż mężczyźni poziom ocenianego lęku i podatności na zranienie, niższy niż mężczyźni poziom impulsywności (neurotyzm) i wyższy poziom ciepła i pozytywnych emocji. lecz niższy - asertywności i poszukiwania wrażeń (ekstrawersja) (Lockenhoff i in., 2014).

Tradycyjny model małżeństwa wynika z koncepcji dychotomii płci i zakłada, że istnieją znaczące różnice między kobietami i mężczyznami, dotyczące sfery biologicznej, psychicznej i osobowościowej, co stanowi predylekcję do pełnienia odmiennych ról społecznych. W tradycyjnym modelu mężczyzna pełni rolę opiekuna i żywiciela rodziny, jego najważniejszym zadaniem jest praca (troska o zasoby materialne rodziny), on też dysponuje władzą - podejmuje decyzje, sprawuje kontrolę, nagradza i karze. Rola kobiety spostrzeganej jako żona - matka polega natomiast na zajmowaniu się domem i rodziną. Żona powinna rodzić dzieci, wychowywać je, dbać o dom i odpowiednią w nim atmosferę. Kobieta powinna cechować się zależnością, posłuszeństwem, czułością, empatią i opiekuńczością (Plopa, 2007, Janicka i Niebrzy- 
dowski, op.cit., Kaźmierczak, op.cit.). Różnica w funkcjonowaniu oparta jest na odmiennym systemie wartości ważnych dla obu płci: instrumentalnych - dominujących w życiu mężczyzn i ekspresyjnych, istotnych dla kobiet.

Egalitarny, oparty na równorzędnych, tzw. partnerskich relacjach między małżonkami model małżeństwa jest modelem bardziej współczesnym. Jego powstanie wiąże się z przekształceniem tradycyjnych ról społecznych. Czynnikiem, który poddał się znaczącej ewolucji jest rola kobiety, która z czasem przestała polegać jedynie na zajmowaniu się domem. Kobiety coraz częściej podejmują pracę zawodową i uzyskują wyższe wykształcenie, pozwalające im robić karierę. $Z$ tej racji, skoro pracę wykonuje zarówno mąż, jak i żona, obowiązki domowe także rozdzielone są między oboje małżonków. Oboje oni zajmują się domem i dziećmi, podejmują ważne decyzje i każde z nich realizuje swoje zainteresowania. W modelu egalitarnym mężczyzna stał się bardziej nastawiony na innych, a kobieta, bardziej niż w modelu tradycyjnym, skupia się na własnej osobie (Kaźmierczak, 2008). Ważna jest możliwość samorealizacji małżonków, istnieje bowiem przekonanie, że związek małżeński nie może ograniczać żadnemu z małżonków rozwoju osobistego, kształcenia się i spełniania pasji (Janicka i Niebrzydowski, 1994). Często wzmocnieniu pozycji kobiety towarzyszy jednak tak istotne osłabienie roli mężczyzny, że uzasadnione jest twierdzenie o kryzysie męskości, którego skutki dotyczą też kolejnych pokoleń. Chłopcy wychowywani w domu, w którym rola ojca uległa dystrofii, pozbawieni są wzoru odwagi, decyzyjności, gotowości do przyjęcia odpowiedzialności za innych, co może tłumaczyć wzrastającą liczbę mężczyzn niegotowych do opuszczenia domu rodziców i założenia rodziny, niezdolnych do decyzji o posiadaniu potomstwa, psychologicznie w dużym stopniu kobiecych (metroseksualnych). Z kolei mężczyźni dorośli, tracąc pozycję głowy rodziny i osoby, do której należy podejmowanie decyzji, czują się zagubieni. Zmiany w obrębie męskości opisują trzy typy mężczyzn: tzw. nowy mężczyzna - schludny, dbający o swoje ciało, opiekuńczy, pozbawiony agresji i w dużym stopniu sfeminizowany, kolejny typ - „nowego chłopaka” oznaczający powrót do tradycyjnego, męskiego stylu zachowania i wreszcie tzw. nowy tata, posiadający dwoistość cech: z jednej strony stanowczy, ale też opiekuńczy. Ewolucja tych ról nie do końca jednak zniosła poczucie zagubienia współczesnych mężczyzn (Bradley, 2008).

Poza tymi rodzajami małżeństw istnieją i inne. W przypadku związku zakładającego równość partnerów - biorąc pod uwagę dziedziczenie majątku, statusu społecznego czy nazwiska można wyodrębnić częściej występujące małżeństwo patrylinearne - w przypadku dziedziczenia po ojcu i matryline- 
arne - w przypadku dziedziczenia po matce (np. Indianie Hopi, Crow i Haida w Ameryce Północnej). Innym czynnikiem różnicującym małżeństwa jest miejsce zamieszkania małżonków po ślubie. Jeśli mieszkają oni w domu rodzinnym mężczyzny - jest to małżeństwo patrylokalne, jeśli w domu kobiety - matrylokalne. Innym kryterium opisu małżeństw jest hierarchia i władza w związku. Zgodnie z tym można wyróżnić małżeństwa patriarchalne, kiedy to mężczyzna jest głową rodziny, matriarchalne, gdy najwyższy autorytet należy do kobiety oraz egalitarne, w których władza partnerów jest zbliżona. Kryterium podziału małżeństw może być także wybór partnera. Gdy małżonkowie wywodzą się z różnych grup etnicznych czy kulturowych, mówimy o małżeństwie egzogamicznym. Gdy związek zawarty jest między osobami z tej samej grupy społecznej, narodowej, rasowej, a także bliskimi sobie w zakresie ich wieku i wykształcenia wówczas jest to małżeństwo endogamiczne (Rostowski, 1987, Janicka i Niebrzydowski, 1994, Adamski, 1984, 1995, Jabłoński, Ostasz, 2001).

Kultura różnicuje także koncepcję struktury związku małżeńskiego, z tego względu można wyodrębnić małżeństwa monogamiczne i poligamiczne. Wśród tych ostatnich występują dwa typy: małżeństwa poliginiczne, kiedy to mężczyzna poślubia kilka kobiet (sytuacja taka występuje wśród muzułmanów czy niektórych społeczności afrykańskich, np. Baganda w Ugandzie i dowodzi dobrego statusu materialnego mężczyzny) oraz małżeństwa poliandryczne, w skład których wchodzi jedna kobieta i kilku mężczyzn. Te małżeństwa są zdecydowanie rzadsze, występują w niektórych plemionach żyjących w Afryce Środkowej lub w hinduskim plemieniu Toda. W państwach europejskich jedynie dopuszczalną strukturą jest monogamia, jest ona najbardziej rozpowszechnioną i najbardziej akceptowaną formą małżeństwa. Jednak w innych kulturach, choćby w arabskiej, jest wiele związków poligamicznych, gdzie jeden mężczyzna może mieć wiele żon i jest to zależne przede wszystkim od jego statusu materialnego. W Afryce znane są plemiona, gdzie to kobieta zawiera poligamiczne związki z wieloma mężczyznami. Z punktu widzenia psychologicznego, związki o strukturze poligamicznej mogą nie być korzystne. Więź emocjonalna pomiędzy partnerami jest w nich słaba, a role społeczne - nieokreślone (Janicka, Niebrzydowski, op.cit.).

Kultura różnicuje także zakres promiskuityzmu. Młodzi ludzie na Samoa czy Wyspach Trobriandzkich mają dużą swobodę i liczne romanse, z których niektóre prowadzą do małżeństwa. W izraelskich kibucach istnieje też duża wolność, lecz stosunkowo mało związków. Chrześcijańska Europa i Ameryka, jak również Indianie Crow stosują często podwójne standardy, 
oczekując „czystości” kobiet i jednocześnie dając prawo mężczyznom do większej swobody w zaspokajaniu ich potrzeb seksualnych. Istnieje wreszcie kulturowe zróżnicowanie w zakresie stosunku do rozwodu i strony inicjującej ten proces. Zwykle decyzja należy do mężczyzny, choć w Dahomeju i Stanach Zjednoczonych częściej o rozwód występują kobiety. W plemieniu Hopi inicjatywa należy do obu stron. Kościół Katolicki całkowicie zakazuje rozwodów, podczas gdy w Rosji (prawosławie) rozwód jest stosunkowo łatwy (Queen i Habenstein, 1967).

\section{Kulturowe kryteria atrakcyjności małżonka}

Rola kultury dotyczy nie tylko rodzajów małżeństw, ale także zaznacza się na początku ich istnienia. Dla powodzenia związku małżeńskiego ważne jest bowiem spełnienie odpowiednich kryteriów wyboru partnera życiowego. Co do tego, jakich - istnieje w tym względzie kilka stanowisk Psychologia ewolucyjna koncentruje się na czynnikach uniwersalnych, w dużym stopniu wolnych od wpływu czynników kulturowych, takich jak: władza, wysoka pozycja społeczna, prestiż wykonywanego zawodu, wiek, inteligencja, pracowitość, stałość w uczuciach, siła fizyczna, dobre zdrowie, miłość i zaangażowanie ważne u mężczyzn oraz wiek, uroda, odpowiednie proporcje w budowie ciała jako predykatory zdrowia i zdolności rozrodczej, ważnych u kobiet (Buss, 2003). W badaniach międzykulturowych uwzględniających ponad 10000 kobiet i mężczyzn z 37 kultur narodowych ustalono listę uniwersalnych preferencji przedstawicieli obu grup mierzonych na skali „nieważna - konieczna” oraz „najbardziej pożądana - najmniej pożądana”. Na pierwszej liście znalazły się: uprzejmy i wyrozumiały, inteligentny, mający ekscytującą osobowość i zdrowy, a na liście drugiej: wzajemna atrakcyjność, emocjonalna stabilność i dojrzałość, bycie godnym zaufania, dobre zdrowie oraz miłe usposobienie (Buss, 1994). Miłość, choć bywa uznawana za pojęcie kultury Zachodu, okazuje się być najwyżej preferowanym czynnikiem związku zarówno wśród Chińczyków, jak i mieszkańców Indonezji, Zambii, Nigerii, Iranu czy Palestyny. Wykazano też różne dla kobiet i mężczyzn, choć ponadkulturowe preferencje. Zgodnie z ewolucyjną teorią Triversa (1972, 1985), która przewiduje, że płeć, która bardziej inwestuje w potomstwo powinna być bardziej wymagająca, we wszystkich badanych kulturach i bez względu na system polityczny (kraje kapitalistyczne, socjalistyczne) kobiety wyżej oceniały „dobre perspektywy finansowe” i „zdolność dobrego zarabiania” kandydata niż mężczyźni. Wszędzie kobiety pragną więcej prawie wszystkiego, co można 
tłumaczyć dążeniem do zagwarantowania ich dzieciom bezpiecznego ekonomicznie życia. Mężczyźni są z kolei bardziej wymagający w odniesieniu do dwóch cech kandydatek na żonę: wieku oraz fizycznej atrakcyjności. Na cały świecie mężczyźni pragną żony młodszej, przy czym w kulturach dopuszczających wielożeństwo, takich jak Zambia czy Nigeria mężczyźni oczekują dużej różnicy wieku -7 lub 8 lat, natomiast w kulturach monogamicznych (Hiszpania, Francja, Niemcy) mężczyźni pragną żony tylko trochę młodszej - o kilka lat. Wszędzie na świecie natomiast kobiety wyżej cenią kandydata starszego: dojrzały mężczyzna ma lepszy dostęp do środków finansowych niż młodszy. Druga cecha kobiet najbardziej pożądana przez mężczyzn, czyli uroda nie jest pochodną subiektywnej oceny, natomiast decyduje o niej zestaw uniwersalnych cech: jasna i elastyczna skóra, brak zmarszczek, błyszczące włosy, pełne wargi, jasne oczy, dobre zdrowie, regularne rysy. W efekcie mężczyźni, bez względu na pochodzenie kulturowe, różny dostęp do środków masowego przekazu, rasową, etniczną, religijną czy polityczną afiliację bardzo wysoko cenią atrakcyjność fizyczną kobiet i są zdolni uznać te same kobiety za piękne. Zarówno młodość, jak i dobry wygląd zwiastują dobre właściwości rozrodcze partnerki.

Jednocześnie w badaniach tych wykazano pewne kulturowe różnice w ocenach cech kandydata na partnera w małżeństwie, które podważają założenia perspektywy ewolucyjnej. Obserwacja taka dotyczy braku wcześniejszych kontaktów seksualnych, które, jak zakładano, powinny być oczekiwane przez mężczyzn na całym świecie. Dziewictwo narzeczonej ma gwarantować bowiem pewność ojcostwa mężczyzny. Uzyskane wyniki przeczą częściowo tym założeniom. Np. zarówno kobiety, jak i mężczyźni z Holandii prawie wcale nie cenią dziewictwa, podobnie jest w Szwecji czy Norwegii. Jednak wśród Chińczyków brak wcześniejszych doświadczeń seksualnych jest uznawany za cechę nieodzowną, równie wysoką cenią tę cechę Palestyńczycy, mieszkańcy Indii, Tajwanu czy Iranu. W innych krajach: w Nigerii, Południowej Afryce, Zambii, Japonii, Estonii, Polsce i Kolumbii dziewictwo jest pożądane w umiarkowanym stopniu. Choć istnieje kulturowe zróżnicowanie wartości dziewictwa, to jednak w dwóch-trzecich wszystkich badanych kultur to mężczyźni w wyższym stopniu oczekują braku wcześniejszych doświadczeń seksualnych swoich partnerek, co potwierdza zakładany ewolucyjny sens tego atrybutu. Triandis (1994) podkreśla z kolei różnicujący kryteria wyboru współmałżonka wpływ indywidualizmu i kolektywizmu. Dla osób wywodzących się z kultury kolektywistycznej szczególnie ważne są: dobry zawód, dziewictwo, lojalność oraz wspólnotowość, natomiast indywidualiści 
preferują ekscytującą osobowość partnera, jego fizyczną atrakcyjność i radość bycia razem.

Inni autorzy wskazują jednak różne od ewolucyjnych kryteria wyboru małżonka, koncentrując się na kulturowo uwarunkowanej zmienności pożądanych cech. Może to być atrakcyjność fizyczna lub podobieństwo, cechy charakteru, temperament lub osobowość, zbliżenie poziomu kulturalnego i religii. Ważny jest także też status społeczny, wykształcenie lub wykonywany zawód. Istotną rolę w wyborze małżonka, związaną z kulturowym tłem, odgrywają też pewne oczekiwania związane z partnerem, ukształtowane na podstawie doświadczeń jednostki, w czym doniosłą rolę odgrywają wzorce osobowe rodziców, wzory pełnionych przeze nich ról i wartości uznawane w rodzinie macierzystej (Ryś, 1999). Badania międzykulturowe ujawniły, że różnie oceniane są takie atrybuty kandydata/tki na partnera w związku, jak: bycie dobrą gospodynią (cenione wysoko w Estonii i Chinach, a nisko - w Europie Zachodniej oraz Ameryce Północnej), subtelność/staranność (wysoko cenione w Nigerii i Iranie, a mniej - w Wielkiej Brytanii, Irlandii i Australii) oraz religijność (wysoko wartościowane w Iranie, umiarkowanie - w Indiach, a nisko - w Zachodniej Europie oraz Ameryce Północnej) (Buss, 1994).

\section{Czynniki satysfakcji małżeńskiej}

Dla związku istotne znaczenie ma podobieństwo partnerów o charakterze endogamii i homogamii. Endogamia jest podobieństwem pod względem kulturowo-społecznym. Bierze się tu pod uwagę rasę, narodowość, wiek, religię, czy przynależność do warstwy społecznej. Homogamia natomiast oznacza podobieństwo psychiczne partnerów, uwzględniające postawy społeczne, wartości, koncepcje ról partnerskich, cechy osobowości (w tym poziom empatii, Kaźmierczak, 2008), czy poziom inteligencji i wykształcenia (Rostowski, 1987, Plopa, 2007), a nawet podobieństwo twarzy (Penton-Voak i in., 1999), czy z pozoru nieważne inicjały imion czy nazwisk (Kopelman i Lang, 1985). Można przyjąć, że obecnie, w dobie odejścia od schematu zwierania małżeństw w ramach tej samej społeczno-kulturowej kategorii, utraty symbolicznego i realnego znaczenia tzw. mezaliansu, homogamia nabiera coraz większego znaczenia dla satysfakcji partnerów w związku (por. Kaźmierczak, op. cit.). Coraz bardziej liczą się ich indywidualne, głównie osobowościowe cechy. Podobieństwo partnerów niewątpliwie redukuje małżeńskie spory, pary homogeniczne tworzą bardziej stabilne i satysfakcjonujące związki i są bardziej płodne (Arrindel i Luteijn, 2000). Podobieństwo daje bowiem większe 
gwarancje sprawnego przebiegu komunikacji oraz identyfikacji ról, a dobry przebieg tych procesów stanowi istotne uwarunkowanie dobranego związku pary małżeńskiej. Ta ogólna zasada znajduje jednak odstępstwa (np. zbyt duża, jak i zbyt mała rozbieżność miedzy partnerami w zakresie neurotyzmu nie jest korzystna dla relacji małżeńskich), ważny także dla funkcjonowania pary jest wpływ sytuacji (Rostowski, 1987).

Z kolei wybór genetycznie podobnej osoby płci przeciwnej może gwarantować wyższy stopień genetycznego pokrewieństwa z potomstwem (Epstein i Guttmann, 1984). Istnieją jednocześnie dowody kontroli stopnia bliskości genetycznej partnerów: prawne oraz subiektywne - ludzie preferują pewien stopień różnicy w procesie selekcji partnerów (Bateson, 1983). Badania międzykulturowe prowadzone wśród małżeństw w USA, Wielkiej Brytanii, Chinach i Turcji wykazały, że mężowie i żony wywodzący się z tych kultur demonstrują preferencje dla podobieństwa w zakresie tych samych wskaźników dominacji (podejmowanie decyzji i zręczność/ zdolności), choć jednocześnie prezentowali specyficzne preferencje dla własnego wpływu na podejmowanie decyzji i stopnia przewagi w zakresie zdolności. Mężowie preferowali własną przewagę w zakresie decyzji i zdolności, choć niezgodnie z koncepcją ewolucyjną - nie oczekiwali własnej przewagi w zakresie zarobków. Żony z kolei były bardziej usatysfakcjonowane, gdy ich mężowie więcej niż one zarabiali, a same miały przewagę w zakresie podejmowania decyzji i zdolności. Wyniki te wskazują na udział w satysfakcji małżeńskiej zarówno czynników ewolucyjnych, kulturowych, jak i osobistych interesów kobiet i mężczyzn (Lucas $\mathrm{i}$ in., 2004).

Ważnym czynnikiem sukcesu małżeńskiego może być bliskość wartości kulturowych, będących jednocześnie elementem podobieństwa endogamicznego (formalna charakterystyka osoby np. pod względem wyznaniowym czy edukacyjnym) oraz homogamicznego (np. siła motywacji budowanej na uznawanych wartościach kulturowych). Przynależność do tej samej grupy rasowej, etnicznej lub narodowościowej niesie za sobą zbliżoną tradycję, hierarchie wartości, przekonania, wpływające na system ocen i sposób komunikowania się bardziej bezproblemowy niż w przypadku par pochodzących z różnych kręgów kulturowych. Prawidłowość ta dotyczy także endogamii w zakresie wyznania. Religia bowiem decyduje w dużym stopniu o postawach wobec tak zasadniczych spraw jak małżeństwo, role płciowe, wychowywanie dzieci, dopuszczalność aborcji. Spełnienie kryterium endogamii pozwała także uniknąć ewentualnej negatywnej oceny społecznej pary, która naruszyła schemat zawierania małżeństwa w obrębie tej samej społeczno-kulturowej grupy. 
Poglądy dotyczące właściwej roli kobiety i mężczyzny w małżeństwie jako predyktor satysfakcji ze związku nie jest jedynie pochodną wyznania, lecz działają także jako element szerzej rozumianej kultury. Badania przeprowadzone wśród studentów wywodzących się z 14 państw wykazały, że istnieje kulturowe zróżnicowanie tych poglądów, a przekonania kobiet na temat ról płciowych były bardziej nowoczesne (równość pozycji) niż opinie mężczyzn (dominacja mężczyzny), choć różnice te były raczej małe. Kultura wydaje się przyczyniać do zróżnicowania ideologii ról płciowych bardziej niż sama płeć, stwierdzono bowiem większą zgodność między kobietami i mężczyznami w tych samych grupach kulturowych niż między kobietami i mężczyznami wywodzącymi się z różnych kultur. Koncepcje ról płciowych były także bardziej egalitarne w krajach wyżej rozwiniętych, chrześcijańskich, bardziej zurbanizowanych i lokowanych na Północy (Holandia, Niemcy, Finlandia) niż w krajach mniej rozwiniętych, z mniejszą liczbą chrześcijan, bardziej rolniczych i położonych blisko równika (Nigeria, Pakistan, Indie) (Williams i Best, 1994).

W różnych społeczeństwach istnieje szereg odmiennych kryteriów i definicji sukcesu małżeńskiego, czy wysokiej jakości małżeńskiej, jest to bowiem zjawisko wielowymiarowe. Może to być zdobycie szczęścia osobistego, czyli pełne przystosowanie małżonków, zadowolenie seksualne, zharmonizowanie osobowości, równowaga emocjonalna i zadowolenie uczuciowe, integracja, dobra komunikacja, zadowolenie ze wspólnej realizacji celów i powodzenie w ich realizacji, wypełnianie zadań małżeństwa, tzn. posiadanie i wychowanie dzieci na wartościowych obywateli, osiągnięcie sukcesu ekonomicznego, tzn. nagromadzenie majątku, spełnienie oczekiwań instytucji religijnych, pełne uczestnictwo małżonków w życiu społecznym, aktywność społeczna i kulturalna w środowisku i osiągnięcie sukcesów w tej działalności (Szczepański 1972; Spanier i Lewis, 1980; Krzyszkowski, 1992). Adamski opisuje dwie płaszczyzny tego sukcesu: sukces subiektywny i obiektywny (1984). Ten pierwszy to zdobycie szczęścia osobistego, osiągnięcie równowagi emocjonalnej, wspólne realizowanie celów życiowych, udane pożycie seksualne (Szewczyk, 2009). Z kolei sukces obiektywny to wychowanie dzieci na mądrych i dobrze funkcjonujących obywateli, zdobycie odpowiednich środków materialnych zapewniających dobre życie (Adamski, 1984; Szewczyk, 2009). Powyższy katalog elementów sukcesu małżeńskiego jest niewątpliwie związany z wartościami kulturowymi. Tam, gdzie dominują wartości indywidualistyczne, większe znaczenie ma osiągnięcie celów ważnych dla jednostki i realizowanych dzięki partnerowi związku (np. poczucie szczęścia, wysokiej jakości życia, zadowolenie seksualne), tam natomiast, gdzie ważne są 
wartości kolektywistyczne, sukces małżeński jest sukcesem wspólnym (np. zadowolenie ze wspólnej realizacji celów, powodzenie w wychowaniu dzieci).

Wartości cenione w życiu uważa się za bardzo ważny predykator szczęścia w związku małżeńskim (Rostowski, 1987). Pozytywny wpływ na jakość małżeństwa mają wartości religijne oraz społeczne i wysoka intensywność przekonań z nimi związanych, w przeciwieństwie do silnych wartości materialnych lub politycznych (Rostowski, op. cit.; Kwiatkowski, 2002). Szczególne miejsce na liście wartości zajmuje miłość rozumiana jako romantyczna siła (wpływająca na całe życie), romantyczny idealizm (miłość jako esencja życia) lub miłość małżeńska (oparta na spokoju i trosce) (Munro i Adams, 1978). Badania międzykulturowe prowadzone przy użyciu Love Attitude Scale wśród uczniów i studentów na Karaibach, w Senegalu, w Ugandzie, w USA oraz Afryce Południowej wykazały pewne różnice w preferencjach dla tych rodzajów miłości: miłość małżeńska była uznawana jako najważniejsza w Ugandzie, Senegalu oraz USA, romantyczny idealizm preferowano na Karaibach, natomiast miłość jako siła romantyczna znalazła uznanie wśród białych i czarnych badanych pochodzących z Afryki Południowej. Jednocześnie stwierdzono na podstawie badań standaryzacyjnych skali, prowadzonych w Kanadzie, że poza czynnikami kulturowymi, dla znaczenia wariantów miłości istotny jest też wiek: osoby starsze bardziej są skłonne cenić miłość małżeńską.

Dość powszechnie uznaje się katalog funkcji małżeństwa. Małżonkowie powinni zaspokajać wzajemnie swoje liczne potrzeby: uczuciowe, emocjonalne, społeczne i seksualne. Zadaniem partnerów jest udzielanie sobie nawzajem pomocy i wsparcia w celu realizacji indywidualnych celów każdego $\mathrm{z}$ nich ważnych dla samorealizacji, powinni oni też współpracować w osiąganiu jak najlepszego statusu ekonomicznego rodziny. Oczywistym celem małżeństwa jest też posiadanie potomstwa, prawidłowe wychowanie dzieci i przekazanie im rodzinnych oraz kulturowych wartości i tradycji (Ziemska, 1979). Queen i Habenstein (1967) wymieniają następujące funkcje rodziny, a wiec i małżeństwa: prokreacja, orientacja, dawanie statusu, ekonomiczna organizacja i produkcja, ochrona młodych, starych i niepełnosprawnych, kontrola zachowania (prowadzenia się) członków grupy oraz przywiązanie (miłość) (s. 17).

Funkcje pełnione przez małżeństwa mogą ulegać modyfikacjom na przestrzeni lat i w związku z pojawiającymi się zmianami kulturowymi. Dotyczy to zwłaszcza małżeństw europejskich czy północnoamerykańskich, w których obserwuje się istotne korekty na przykład funkcji prokreacyjnej Kiedyś 
uważana za najważniejszą w związku małżeńskim, obecnie nie odgrywa już takiej roli. Wiele młodych małżeństw skupia się na karierze zawodowej, posiadanie dzieci spostrzegając jako przeszkodę w realizacji planów i marzeń. Znaczenie ma także aktywność zawodowa kobiet. Decyzja o dziecku zostaje przekładana na późniejsze lata związku. Małżeństwa także coraz rzadziej decydują się na posiadanie kilkorga dzieci, kiedy wcześniej ich obecność sprzyjała realizacji funkcji produkcyjnej rodziny. Zmiany cywilizacyjne i kulturowe zmniejszyły zdecydowanie znaczenie tego rodzinnego zadania, pozostawiając je jedynie w gestii rodzin rolniczych. Rodzina w coraz mniejszym stopniu jest instytucją, a coraz bardziej zespołem koleżeńskim nie zmuszanym do podejmowania działań służących przeżyciu (Queen i Habenstein, 1967). Jest też zespołem coraz mniejszym: w 1790 roku, na początku powstania Stanów Zjednoczonych rodzinę tworzyło średnio 5.7osób, podczas gdy w roku 1965 tylko 3,7 (op.cit.).

Rządowa Rada Ludnościowa (2011) podaje, że w roku 2010 w Polsce zawartych zostało 228,3 tys. małżeństw, co stanowi o ponad 30. tys. mniej niż w roku 2009. Od roku 2008 liczba zawieranych w Polsce małżeństw systematycznie maleje. Analiza bilansu urodzeń i zgonów w skali świata wskazuje, że poza czynnikami cywilizacyjnymi i politycznymi, istnieje wpływ wartości kulturowych na rozwój demograficzny państw: depresja demograficzna obserwowana jest $\mathrm{w}$ krajach $\mathrm{z}$ dominantą wartości indywidualistycznych, a progres demograficzny w krajach z orientacją kolektywistyczną. W dniu 26 sierpnia 2013 roku bilans urodzeń i zgonów w Chinach wyniósł 22966 osób, a w Indiach - 42 367, podczas gdy w Niemczech był ujemny (minus 249 osób), natomiast w Wielkiej Brytanii przybyło 977 osób. Biorąc pod uwagę bilans roczny, uwzględniający wielkości populacji krajów, rozwój Hindusów wynosi 1,24\%, Chińczyków - przy polityce „jednego dziecka” - 0,61\%, mieszkańców Gwatemali - 2,51, a Nigerii - 3,85\%. Kraje zachodnie takich osiągnięć demograficznych nie mają: w Niemczech bilans wynosi-0,11\%, we Włoszech - 0,21\%, w Wielkiej Brytanii - 0,57\%, a w USA - 0,81\%, przy czym wiele dzieci w tych państwach rodzą imigrantki. Polska walczy o przetrwanie z rocznym bilansem 0,01\% (United Nations, 2013). Obecna polityka demograficzna rządu ma na celu odwrócenie tej negatywnej tendencji.

\section{Problemy małżeństw wielokulturowych}

Szczególnym problemem w badaniach psychologii międzykulturowej są małżeństwa wielokulturowe, w których partnerzy wnoszą różne doświadczenia 
i tradycje. Ich zawieraniu sprzyja tendencja do egalitaryzmu i sekularyzacja, odrzucanie zewnętrznej presji na personalne wybory, a także zmniejszenie znaczenia prokreacji w małżeństwie. Czynniki te osłabiają zaangażowanie w grupy spójne, endogamiczne i zwiększają gotowość wychodzenia poza grupę własną.

W złożonych społeczeństwach istnieją trzy główne linie separujące grupy osób: religia, rasa oraz etniczność. Dodać do nich należy to samo pochodzenie etniczne, lecz różną narodowość (np. sytuacja Greków mieszkających w Grecji i na Cyprze). One też stanowią podstawę głównych form małżeństw mieszanych (intermarriage) (Cerroni-Long, 1984). Ludzie, którzy żenią się poza grupą własną naruszają rasowe, etniczne, religijne czy narodowe kryteria podziałów i ich kombinacje. Ponieważ u podstaw każdej z tych kategorii tkwi określony katalog wartości kulturowych, można w każdym z tych przypadków mówić o małżeństwach wielokulturowych. Koniecznym warunkiem zawarcia tego typu małżeństw jest dostępność fizyczna, aktualna oraz psychologiczna partnera z innej niż własna grupy. Dostępność fizyczna oznacza proporcje płci (nierównowaga płci sprzyja zawieraniu małżeństw mieszanych przez członków grupy dominującej liczebnie pod tym względem) oraz wielkość grup (im większa grupa, tym większe prawdopodobieństwo tego typu związków). Aktualna dostępność oznacza obecność potencjalnego partnera w sytuacji, która pozwala urealnić ten związek. Czynnikiem ograniczającym tego rodzaju dostępność są np. zakazy religijne czy normy społeczne, formalne i nieformalne, umacniające segregację społeczną i spójność grupy własnej, natomiast sprzyja jej duża częstość kontaktów w sytuacjach umożliwiających zaangażowanie emocjonalne. Wreszcie psychologiczna dostępność oznacza, że małżeństwo członków dwóch endogamicznych grup odpowiada proporcji kompatybilności między tymi grupami (Cerroni-Long, op. cit.). Istnieją jeszcze inne przyczyny decyzji o małżeństwie poza grupą własną. Sprzyja jej uznawanie norm grupowych jako niewiążących, gdy dominuje osobista interpretacja norm (np. brak nacisku na spójność grupową), wyjątkowe okoliczności - wojna, emigracja, utrata więzi z grupą pochodzenia w warunkach osłabienia wiary czy akulturacji. W takich okolicznościach zawarcie małżeństwa mieszanego traktowane jest jako wyraz nonkonformizmu. Kolejny powodem jest świadome naruszenie norm dla uzyskania specyficznych nagród - społeczno-kulturowych i ekonomicznych (małżeństwo jest wtedy „wymianą") oraz nagród psychologicznych (małżeństwo jako sposób spełnienia specyficznych oczekiwań grupowych). Istnieją wreszcie powody osobiste: pragnienie spełnienia personalnych celów lub potwierdzenia obrazu Ja (mał- 
żeństwo jako droga osiągnięcia celów), a także problemy natury mentalnej (poczucie nieadekwatności, alienacja wobec grupy własnej, rebelia wobec norm tej grupy oraz autorytetów - rodziców, rówieśników i inne). W tym ostatnim przypadku małżeństwo mieszane ma służyć rozwiązaniu problemów mentalnych) (Cerroni-Long, op.cit.).

Nie tylko decyzja o zawarciu małżeństwa z osobą pochodzącą z innej grupy i wnoszącą odmienny system wartości kulturowych i obyczajów obarczona jest trudnościami. Także samo małżeństwo podlega działaniom czynników stresowych należących do trzech kategorii: personalnych, zewnętrznych oraz losowych. Czynniki osobiste to czynniki związane z interakcjami między dwoma partnerami i wpływem ich indywidualnych problemów, czynniki zewnętrzne związane są z interakcją między małżonkami i wszystkimi osobami, które wchodzą z nimi w kontakt, natomiast losowe nie mogą być przewidziane, ponieważ dotyczą zaskakujących zdarzeń w życiu małżeństwa, wydarzeń historycznych czy procesów zmiany społeczno - kulturowej. Wśród zwykłych czynników odpowiedzialnych za trudności życia świeżo poślubionych małżonków (np. konfrontacja rzeczywistości z wyobrażeniami) w małżeństwach mieszanych dołącza się rola stereotypów grupy, z której wywodzi się partner oraz trudności w komunikowaniu się związane z różnicami ich społeczno kulturowego backgroundu. Różnice te odpowiadają za problemy w wyrażaniu emocji czy nadawanie tych samych znaczeń pojęciom i sytuacjom. Konieczne są negocjacje dotyczące używanego języka, a wybór języka partnera może być interpretowany jako dowód większej akceptacji dla grupy obcej etnicznie i przez to oceniany negatywnie. Jednocześnie wybór ten może wywoływać w odpowiedzi większą akceptację ze strony członków innej grupy językowej (Bond i Cheung, 1984). Oddzielną kwestią jest problem dwujęzyczności, zwłaszcza jako standard wychowania dzieci urodzonych w małżeństwach wielokulturowych. Źródłem stresu i wzajemnej agresji może być niezrozumienie lub nieprzestrzeganie reguł komunikacyjnych obowiązujących w odmiennej kulturze. Tak więc wrogie reakcje mogą towarzyszyć zachowaniom osoby wywodzącej się z kultury małego dystansu władzy, jeśli ocenia publicznie osobę zajmującą wysoką pozycję w kraju z dominantą wartości dużego dystansu. I odwrotnie - osoby realizujące kulturowy wzór równości zareagują awersyjnie na osobę dyrektywną. Z kolei różnice w komunikowaniu się osób wywodzących się z kultury indywidualistycznej i kolektywistycznej sprowadzają się do różnicy między komunikacją niskiego (indywidualizm) i wysokiego (kolektywizm) kontekstu. Ta pierwsza ma miejsce wtedy, gdy „większość informacji mieści się w kodzie bezpośrednim”, natomiast istotą drugiej jest to, że „więk- 
szość informacji bądź zawiera się w fizycznym kontekście, bądź jest zinternalizowana w człowieku, a tylko nieznaczna jej część mieści się w zakodowanej, bezpośrednio nadawanej części przekazu" (Hall, 2001, s. 95). Mówiąc inaczej, osoby pochodzące z kultury niskiego kontekstu są socjalizowane w kierunku dostarczania partnerowi względnie precyzyjnego, bezpośredniego i werbalnego sprzężenia zwrotnego, podczas gdy osoby wychowane w kulturze wysokiego kontekstu są skłonne dostarczać feedbacku nieokreślonego, opóźnionego, niewerbalnego i nie kierowanego ku konkretnej osobie. Te i inne jeszcze różnice stwierdzono na przykład w zachowaniach komunikacyjnych Żydów (kultura indywidualistyczna) i Arabów (kultura kolektywistyczna) w Izraelu: ci pierwsi wykazywali skłonność do mówienia „kierowanego wprost” i uporządkowanego, podczas gdy drudzy „klucząc” ustępowali i dostosowywali się do stanowiska partnera (Katriel, 1986).

Wiele problemów może przysparzać także sposób traktowania czasu. W kulturach indywidualistycznych funkcjonuje linearny model czasu, zdarzenia mają początek, środek i koniec, czyli istnieją trzy kategorie czasowe: przeszłość - teraźniejszość i przyszłość. Funkcjonują też sztywne normy dotyczące czasu, a każde spóźnienie się jest traktowane jako ich naruszenie. Obecna jest presja na realizację planu zajęć rozpisanych w określonym czasie, a działania są uporządkowane (po zakończeniu jednego - kolejne). Z kolei w kulturach kolektywistycznych ludzie mają bardziej elastyczne postawy wobec czasu, co wyraża się mniej rygorystycznym przestrzeganiem terminów umówionych spotkań. Czas jest opisywany w kategorii koła, co oznacza, że nie ma on początku, środka i końca lub są one nieznane, stąd też różne czynności można wykonywać powoli i równocześnie (Smith i Bond, 1994; Laungani, 2007). Kultura determinuje też różnice w stylu atrybucji. W krajach o orientacji kolektywistycznej istnieje kult wysiłku, natomiast w krajach indywidualistycznych większe znaczenie przywiązuje się do zdolności. Może to być źródłem błędnych atrybucji: przyczyny zdarzeń podawane przez obcokrajowca mogą być inne od tych, które podaje członek własnej kultury (op. cit.). Jednocześnie w przypadku małżeństw wielokulturowych wytwarza się specyficzna mikrokultura, która przyczynia się do koncentracji na ekologicznym kontekście zadań, co jest sposobem unikania konfrontacji między „moją" i „twoją" kulturą. Kiedy pojawiają się różnice, partnerzy skłonni są przypisywać trudności raczej kulturowemu tłu niż osobowości małżonka (Fontaine, 1990).

Źródłem stresu mogą być także krewni, którzy nie akceptują takiego małżeństwa sądząc, że jest ono naruszeniem rodzinnej sieci lub kiedy stają się 
świadkami niezgody wynikającej z braku przystosowania „obcego” partnera do struktury rodziny. Przyczyną stresu zewnętrznego mogą być także dzieci będące obiektem sporu dotyczącego kulturowych zasad ich wychowania, co przyczynia się do wzajemnej wrogości rodziców, która może generalizować się na stosunek do ich grup pochodzenia.

Wśród losowych czynników stresu doświadczanego przez małżeństwa mieszane wyróżnia się proces zmiany społecznej, która wpływa na każde małżeństwo, także wielokulturowe, przekształcając przede wszystkim koncepcję statusu kobiety. Zmieniają się stereotypowe wyobrażenia jej roli, o co łatwiej w nowoczesnych społeczeństwach zachodnich, choć proces ten obserwuje się także w podlegających modernizacji społeczeństwach tradycyjnych. Zmiana społeczna powoduje, że koncepcja rodziny, małżeństwa i miłości podlega nowej interpretacji i wpływa na relacje małżeńskie i rodzinne (Cerroni-Long, op.cit.).

Ważnym czynnikiem stresu jest też emigracja i zamieszkanie pary małżeńskiej w środowisku obcym kulturowo. Z wyników badań nad adaptacją tureckich małżeństw badanych w Kanadzie wynika, że istnieje szereg predykatorów adaptacji psychologicznej (poziom depresji, stresu, lęku i satysfakcji z życia), socjokulturowej (doświadczenie trudności w 23 sytuacjach społecznych) oraz adaptacji małżeńskiej (wzajemne przystosowanie małżonków) (Ataca i Berry, 2002). Wyznacznikiem poziomu adaptacji psychologicznej małżeństw okazały się: odporność, okres pobytu, wsparcie społeczne (działanie pozytywne), a także strategia marginalizacji (działanie negatywne). Za dobre przystosowanie socjokulturowe odpowiada biegłość językowa i częsty kontakt z gospodarzami, natomiast adaptacji małżeńskiej sprzyja wsparcie małżeńskie, podczas gdy działanie opozycyjne ma małżeński stres. Choć wsparcie społeczne okazało się równie ważne dla obojga małżonków, to stres doświadczany w małżeństwie był niekorzystny zwłaszcza dla kobiet. Ma to uwarunkowanie kulturowe związane $\mathrm{z}$ tradycyjnym w rodzinach tureckich podporządkowaniem kobiety mężczyźnie i dużym znaczeniem przywiązywanym przez kobiety do związku (Kagitcibasi, 1986), co każde zaburzenie w nim czyni źródłem ich psychologicznej nierównowagi. Istotnym źródłem stresu kobiet może być także odpowiedzialność za wychowanie dzieci bez wsparcia szerszej rodziny. Uzyskane wyniki potwierdzają inne studia nad uwarunkowaniami udanej adaptacji kulturowej (por. Miluska, 2003).

Badania nad stresem doświadczanym przez małżeństwa i rodziny wielokulturowe oraz opracowanie efektywnych programów radzenia sobie z nim wydaje się być ważnym zadaniem dla psychologii w warunkach coraz in- 
tensywniejszych kontaktów międzykulturowych owocujących tworzeniem różnego rodzaju związków interpersonalnych.

\section{Bibliografia}

Adamski, F. 1984. Socjologia matżeństwa i rodziny. Wprowadzenie. Warszawa: PWN.

Adamski, F. 1995. Miłość. Matżeństwo. Rodzina. Kraków: WAM

Arrindel, W. A. i Luteijn, F. 2000. Similarity between intimate partners for personality traits as related to individual levels of satisfaction with life. Personality and Individual Differences. 28, pp. 629-637.

Ataca, B. i Berry, J. W. 2002. Psychological, sociocultural, and marital adaptation of Turkish immigrant couples in Canada. International Journal of Psychology. 37, 1, pp. 13-26.

Bates, P.P.G. 1983. Optimal outbreeding. In: Bateson, P.P.G. (ed.). Mate choice. Cambridge: Cambridge University Press, pp. 257-277.

Bond, M.H. and Cheung, M.K. 1984. Experimenter language choice and ethnic affirmation by Chinese trilinguals in Hong Kong. International Journal of Intercultural Relations. 8, pp. 347-356.

Bradley, H. 2008. Płeć. Warszawa: Wydawnictwo Sic!

Buss, D. 1994. Mate preferences in 37 cultures. In: Lonner, W.J. and Malpass, R.S. eds. Psychology and culture. Needham Heights: Allyn and Bacon.

Buss, D. 2003. Ewolucja pożądania. Gdańsk: GWP.

Cerroni-Long, E.L. 1984. Marrying Out: Socio-Cultural and Psychological Implications of Intermarriage. Journal of Comparative Family Studies. XVI, 1, pp. 28-45.

Costa, P.T. and McCrae, R.R. 1992. Professional manual: Revised NEO-Five-Factor Inventory. Lutz: Psychological Assessment Resources.

Epstein, E. and Guttman R. 1984. Mate selection in man: evidence theory and outcome. Social Biology.31, pp. 243-278.

Fontaine, G. 1990. Cultural diversity in intimate intercultural relationships. In: Cahn, D. ed. Intimates in conflict: A communication perspective. Hillsdale: Erlbaum.

Hall, E. 2001. Poza kultura. Warszawa: PWN.

Jabłoński, D. i Ostasz, L. 2001. Zarys wiedzy o rodzinie, małżeństwie, kohabitacji i konkubinacie. Olsztyn: Adiaphora. 
Janicka, I. i Niebrzydowski, L. 1994. Psychologia matżeństwa. Zafascynowanie partnerem. Otwartość. Empatia. Miłość. Seks. Łódź: UŁ.

Kagitcibasi, C. 1986. Status of women in Turkey, Cross-cultural perspectives. International Journal of Middle East Studies. 18, pp. 485-499.

Katriel, T. 1986. Talking straight: Dugri speech in Israeli Sabra culture. New York: Cambridge University Press.

Kaźmierczak, M. 2008. Oblicza empatii w relacjach matżeńskich. Perspektywa psychologiczna. Gdańsk: UG.

Kopelman, R.E. and Lang, D. 1985. Alliteration in mate selection: does Barbara marry Barry? Psychological Reports. 56, pp. 791-796.

Krzyszkowski, J. 1992. Familiocentryzm a praktyka życia rodzinnego młodych Polaków, Jugend und Wertewandel in Polen und der Bundesrespublik Deutschland. Deutsches Jugendinstitut (Hrs) Monachium, pp. 137-151 .

Kwiatkowski, P. 2002. Preferowane wartości a zadowolenie z małżeństwa. Matżeństwo i Rodzina. 2, ss. 28-31.

Laungani, P.D. 2007. Understanding cross-cultural psychology. Eastern and Western perspectives. London: Sage.

Lockenhoff, C.E., Chan, W., McCrae, R.R., De Fruyt, F., Jussim, L., De Bolle, M., Costa, P.T. Jr., Sutin, A R., Realo, A., Allik, J., Nakazato, K., Shimonaka, Y., Hrebickova, M., Graf, S., Yik, M., Fickova, E., Brunner-Sciarra, M., Leibovich de Figueora, N., Schmidt, V., Ahn, C., Ahn, H.N., Aguilar-Vafaie, M.E., Siuta, J., Szmigielska, B., Cain, T.R., Crawford, J.T., Mastor, K.A., Rolland, J.,P., Nansubuga, F., Miramontez, D.,R., Benet-Martinez, V., Rossier, J., Bratko, D., Marusic, I., Halberstadt, J., Yamaguchi, M., Knezevic, G., Martin, T.A., Gheorghiu, M., Smith, P.,B., Barbaranelli, C., Wang, L., Shakespeare-Finch, J., Lima, M.,P., Klinkosz, W., Sękowski, A., Alcalay, L., Simonetti, F., Avdeyeva, T.,V., Pramila, V.,S. and Terracciano, A. 2014. Gender stereotypes of personality: Universal and accurate? Journal of Cross-Cultural Psychology. 45 (5), pp. 675-694.

Lucas, T.W., Wendorf, C.A., Imamoglu, E.O., Shen, J., Parkhill, M.R., Weisfeld, C.C. and Weisfeld, G.E. 2004. Marital satisfaction in four cultures as a function of homogamy, male dominance and female attractiveness. Sexualities, EvolutionE Gender. 6, pp. 2-3, 97-130.

McCrae, R.R., Terracciano, A. \& 78 Members of the Personal Profiles of Cultures Project. 2005. Universal features of personality traits from the observer's perspective: Data from 50 cultures. Journal of Personality and Social Psychology. 88, pp. 547-561. 
Miluska, J. 2003. Proces akulturacji a agresja społeczna. W: Ambrozik W. i Zieliński F. red. Młodociani mordercy. Studia nad agresja i zbrodniq. Poznań: PTPN, ss. 133-150.

Munro, B. and Adams, G. 1978. Love American style: a test of role structure theory on changes in attitudes toward love. Human Relations. 31, pp. 215-228. Nowa Encyklopedia Powszechna PWN. T. IV. 1997. Warszawa: PWN.

Penton-Voak, I.S., Perrett, D.I. and Peirec, J.W. 1999. Computer graphic studies of the role of facial similarity in judgments of attractiveness. Current Psychology, 18, pp. 104-188.

Plopa, M. 2007. Psychologia rodziny: teoria i badania. Kraków: Oficyna Wydawnicza Impuls.

Queen, S.A. and Habenstein, R.W. 1967. The family in various cultures. Philadelphia: Lippincott Company.

Rostowski, J. 1987. Zarys psychologii matżeństwa. Psychologiczne uwarunkowania dobranego związku matżeńskiego. Warszawa: PWN.

Ryś, M. 1999. Psychologia matżeństwa w zarysie. Warszawa: Centrum Metodyczne Pomocy Psychologiczno-Pedagogicznej MEN.

Rządowa Rada Ludnościowa 2011. Raport z 2011. Warszawa, www.stat.gov. $\mathrm{pl} / \mathrm{cps} / \mathrm{rde} / \mathrm{xbcr} / \mathrm{bip} /$ BIP_raport_2010-2011.pdf (18.12 2012).

Samson, A. 2001. Jak przetrwać w matżeństwie. Warszawa: Wydawnictwo Książkowe Twój Styl.

Smith, P.B. and Bond, M.H. 1994. Social psychology across cultures. Analysis and perspectives. Needham Heights: Allyn\& Bacon.

Schmidt, D.P., Realo, A., Voracek, M. and Allik, J. 2008. Why can't a man be more like a women? Sex differences in Big Five personality traits across 55 cultures. Journal of Personality and Social Psychology. 94, pp. 168-182. Spanier, G.B. and Lewis, R.A. 1980. Marital quality. A review of the seventies. Journal of Marriage and the Family. 42, pp. 825-839.

Szewczyk, M. 2009. Szczęście małżeńskie w perspektywie psychologiczno-socjologicznej. W: Muszyński W. red. Kocha się raz? Toruń: Wydawnictwo Adam Marszałek.

Szczepański, J. 1972. Elementarne pojęcia socjologii. Warszawa: PWN. Terracciano, A., Abdel-Khalek, A.M., Adam, N., Adamova, L, Ahn, C., Ahn, H.N. and McCrae R.R. 2005. National character does not reflect mean personality traits levels in 49 cultures. Science. 301, pp. 96-100.

Triandis, H.C. 1994. Culture and Social behawior. In: Lonner, W.J. and Malpass, R.S. eds. Psychology and culture. Needham Heights: Allyn and Bacon. 
Trivers, R. 1972. Parental investment and sexual selection. In: Campbell B. ed. Sexual selection and the descent of man: 1871-1971. Chicago: Aldine.

Trivers, R. 1985. Social evolution. Menlo Park: The Benjamin/Cummings Publishing Company.

United Nations. Department of Economic and Social Affairs. Population Division. 2013. www.geohive.com/earth/population_now. aspx

Williams, J.E. and Best, D.L. 1994. Cross-cultural views of women and men. In: Lonner, W.J. and Malpass, R.S. eds. Psychology and culture. Needham Heights: Allyn and Bacon.

Ziemska, M. 1979. Rodzina a osobowość. Warszawa: „Wiedza Powszechna”.

\title{
Marriage in the perspective of intercultural studies
}

\begin{abstract}
The development of culture psychology and intercultural studies provides new tools for describing and analysing the institution of marriage. It is not any longer only a system of specified functions but also a relation of which the features and the way of functioning is largely regulated by cultural values and norms. The concepts of cultural values constitute a good foundation for interpreting marital life in the context of comparisons between various systems of values. They explain how love is defined as an important principle of couple matching and how marital relations are shaped (power, mutual attractiveness, communication, conflicts and negotiations), especially in the case of multicultural marriages, into which partners bring in different experiences and traditions.
\end{abstract}

Keywords: culture psychology, marriage, multicultural marriage, intercultural studies 